\title{
DOING BUSINESS
}

IN FINLAND

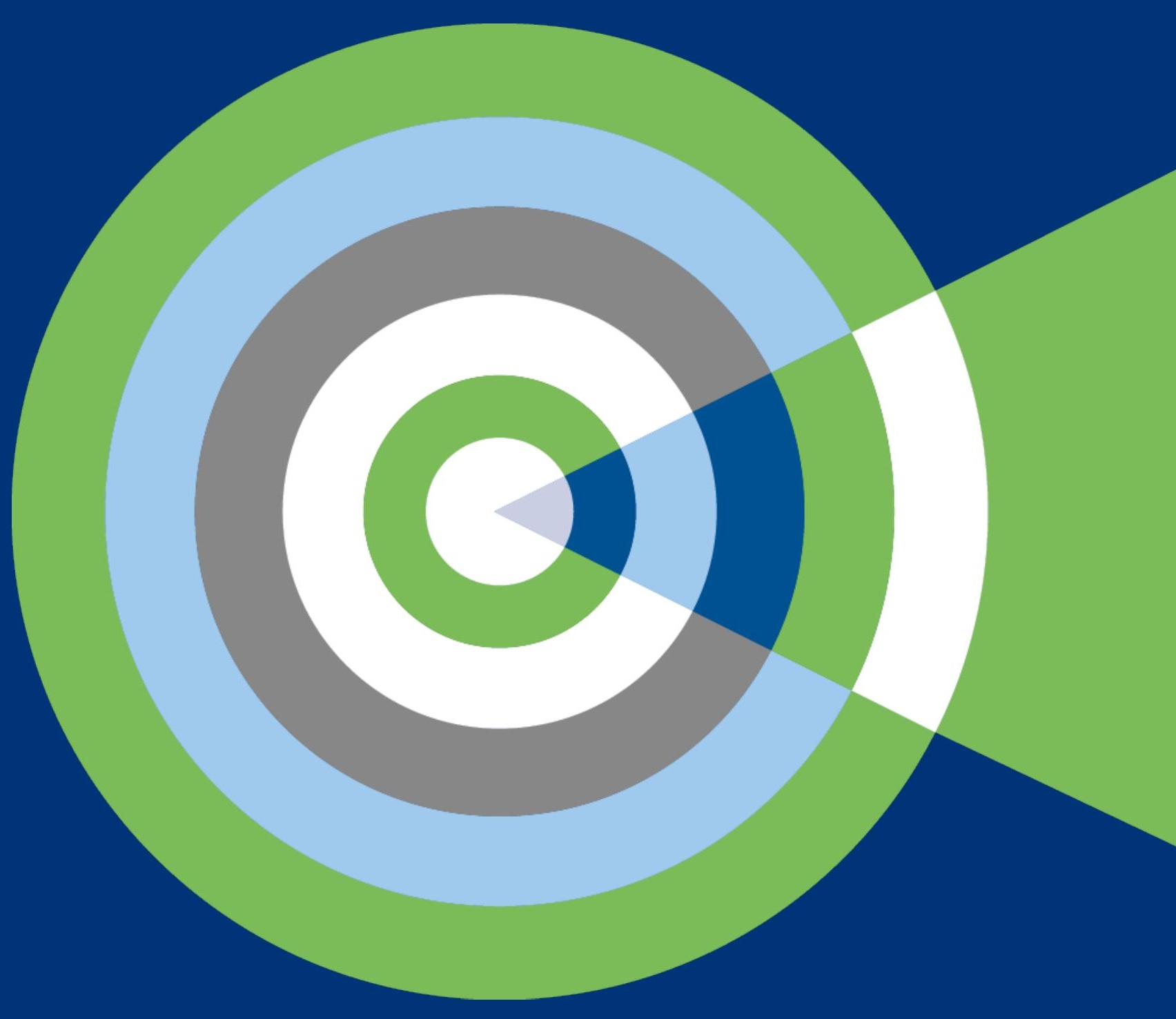

The network for doing 


\section{CONTENTS}

1-Introduction

2-Business environment

3- Foreign Investment

4 - Setting up a Business

5-Labour

6-Taxation

7- Accounting \& reporting

8 - UHY Representation in Finland

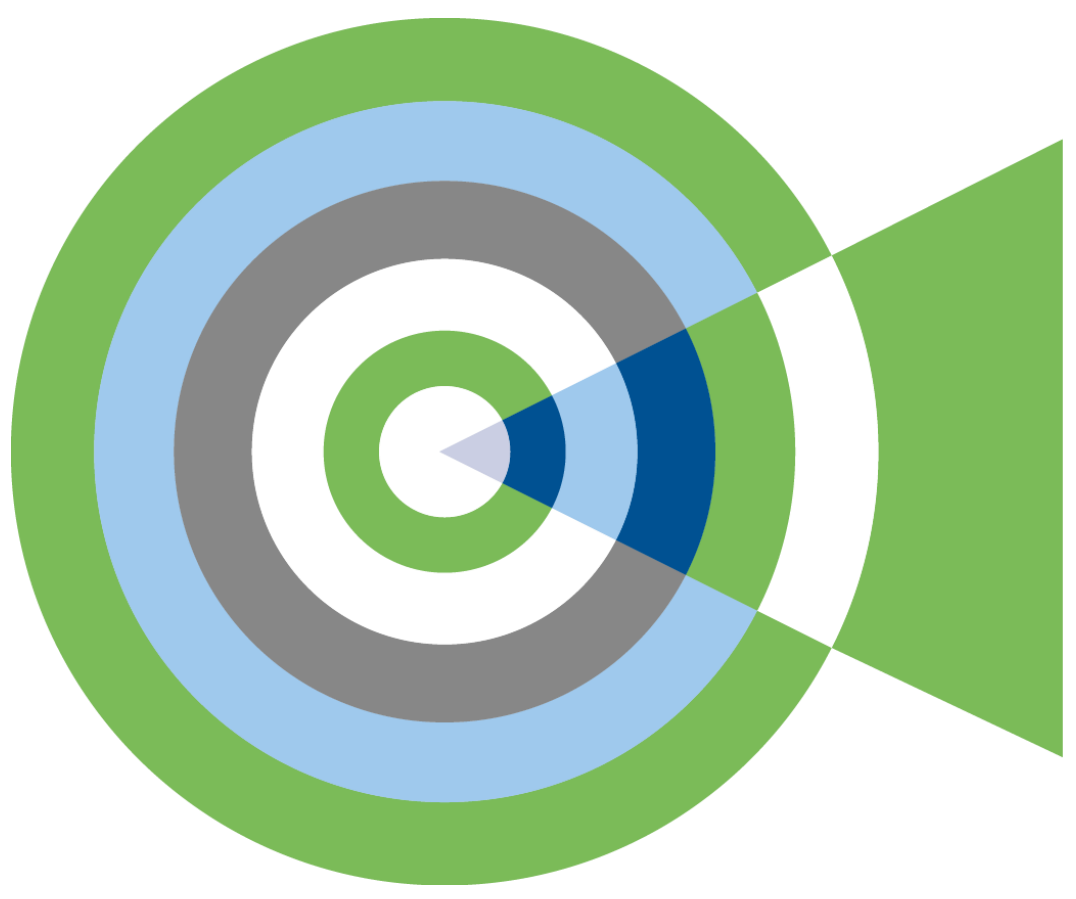




\title{
$1-$ INTRODUCTION
}

UHY is an international organisation providing accountancy, business management and consultancy services through financial business centres in around 100 countries throughout the world.

Business partners work together through the network to conduct transnational operations for clients as well as offering specialist knowledge and experience within their own national borders. Global specialists in various industry and market sectors are also available for consultation.

This detailed report providing key issues and information for investors considering business operations in Finland has been provided by the office of UHY representatives:

\author{
UHY TIETOAKSELI \\ Puistokatu $2 \mathrm{C}$ \\ 40100 Jyväskylä \\ Finland \\ Phone $\quad+358103472800$ \\ Website www.tietoakseli.fi \\ Email info@tietoakseli.fi
}

You are welcome to contact Samuel Akselin (samuel.akselin@tietoakseli.fi), Petri

Korkiamäki (petri.korkiamaki@tietoakseli.fi) or Sanna Vähäkömi

(sanna.vahakomi@tietoakseli.fi) for any inquiries you may have.

Information in the following pages has been updated so that they are effective at the date shown, but inevitably they are both general and subject to change and should be used for guidance only. For specific matters, investors are strongly advised to obtain further information and take professional advice before making any decisions. This publication is current at September 2020.

We look forward to helping you do business in Finland.

UHY TietoAkseli is a member of Urbach Hacker Young International Limited, a UK company, and forms part of the international UHY network of legally independent accounting and consulting firms. UHY is the brand name for the UHY international network. The services described herein are provided by the Firm and not by UHY or any other member firm of UHY. Neither UHY nor any member of UHY has any liability for services provided by other members. 


\section{2 - BUSINESS ENVIRONMENT}

\section{BACKGROUND}

The business environment in Finland is easy and efficient.

The public and private sector are both committed to investing in research and development and the country's highly educated people have a positive can-do attitude towards innovation. Finland has a free-market economy with a highly industrialised manufacturing sector.

\section{AREA}

At 338,000 square kilometres, Finland is the seventh largest country in Europe in terms of area. The landscape is dominated by lakes and forests and Finland is sparsely populated with 15.7 inhabitants per square kilometre.

\section{POPULATION}

The population of Finland is 5.5 million. $67 \%$ of people live in towns or urban areas and $33 \%$ in rural areas. The majority of the population is concentrated in the southern region.

\section{CAPITAL}

The capital is Helsinki. About 1.5 million people live in the Helsinki metropolitan area.

\section{LANGUAGES}

There are two official languages in Finland; Finnish and Swedish. In addition, about 1,700 people in Lapland speak Sami languages. English is an important business language.

\section{POLITICAL SYSTEM}

Finland has been an independent republic since 1917 with the president of the republic acting as head of the state. The president is elected every six years.

Finland is a democracy with a single-chamber parliament of 200 members. The parliament members are elected every four years.

Finland has been a member of the European Union (EU) since 1 January 1995 and a member of the European monetary Union since 1999.

\section{CURRENCY}

The country's currency is the euro.

\section{TABLE 1}

Key economic indicators

Gross Domestic Product (GDP) EUR 240.60 billion

2019

GDP per capita 2019 EUR 43, 567

Unemployment rate 2019

$6,7 \%$

Inflation rate 2019

$1.0 \%$

Enterprises 2018 


\begin{tabular}{ll}
\hline Enterprises established 2019 & 38,521 \\
\hline Enterprises closed 2019 & 21,812 \\
\hline General government deficit 2019 & $1.1 \%$ of GDP \\
\hline General government debt 2019 & $59.4 \%$ of GDP \\
\hline
\end{tabular}

IMPORTED PRODUCTS

In 2019 the main importing industry sector was metal, machine and transport equipment industry products with the share of $29,6 \%$ followed by chemical industry products with $17,4 \%$ and electric and electronics industry products with $14,1 \%$.

\section{EXPORTED PRODUCTS}

Finnish exports in 2019 totalled 64.9 billion Euros. The largest volumes of exported products were forest, metal, chemical and electrical equipment.

MAIN TRADING PARTNERS

In 2019, the country's main trading partners were Germany, Sweden, Russia, United States, Netherlands and China. 


\section{3 - FOREIGN INVESTMENT}

\section{INVESTMENT BACKGROUND}

Finland is a small country located in the fast-growing markets of Northern Europe, which is home to 80 million consumers.

Finland's long experience of trade in Northern Europe, combined with its historical and cultural ties to neighbouring countries, offers insight and knowledge into the region.

Finland is an advanced industrial economy with a thriving private sector and a business environment which is highly conducive to foreign direct investments. The government is business-friendly and Finland has a developed infrastructure, a skilled workforce and competitive operating costs. According to World Economic Forum's 'Global Competitiveness Report 2019', Finland ranked as the $11^{\text {th }}$ most competitive economy. The report gave especially high scores (ranking in parentheses) on Institutions (1), Health and primary education (1), Higher education and training (2), Financial market development (4) and Innovation (1). It is fair to say that Finland has the best availability of scientists and engineers in the world and they are trained by one of the best education systems in the world.

Finland's multi-party democracy is characterised by a strong penchant towards consensus and pragmatic policies implemented by coalition governments. Finland is also one of the least corrupt countries in the world according to Transparency International ( $3^{\text {rd }}$ place in 2019).

\section{FOREIGN DIRECT INVESTMENT}

Foreign direct investments (FDI) in Finland totalled EUR 62,4 million in 2018. The biggest share of FDI came from Benelux Countries, Sweden, and Denmark. 


\section{4 - SETTING UP A BUSINESS}

\section{BUSINESSES}

Business in Finland may be carried on by a private entrepreneur or in the form of a company.

The forms of Finnish companies are a general partnership, limited partnership, limited company (the most common vehicle for conducting business in Finland) and co-operative. A foreign company may also run a business in Finland through a branch.

\section{PRIVATE ENTREPRENEUR (TMI / FMA)}

The simplest way to set up a business in Finland is to form a private enterprise. A natural person who is resident in the European Economic Area (EEA) may carry out the trade in the form of a private enterprise. If a person willing to set up a private enterprise is residing outside the EEA, he/she needs to have a trade permit which can be granted by The National Board of Patents and Registration (NBPR).

GENERAL PARTNERSHIP (AY / ÖB)

A general partnership has to have at least two partners. The partners (ie the founders) can be a natural or legal person which means that another general partnership may act as a founder. At least one partner of a general partnership should be a resident or have the registered office in the EEA. If any of the partners do not meet the demands described, all the partners who are not from the EEA shall apply for a permit from the National Board of Patents and Registration.

A general partnership can be formed without a cash input. The partners of a general partnership are always liable with their entire property for the commitments of the partnership.

\section{LIMITED PARTNERSHIP (KY / KB)}

To form a limited partnership, there must be at least two partners. At least one partner has to be a general partner and at least one partner has to be a silent partner.

A general partner (also called an active partner) does not need to invest cash or other capital to the partnership, but a silent partner should invest cash or other capital input. The general partner is liable with their entire property for the commitments of the partnership. The liability of a silent partner is however limited to the amount of his/her capital investment indicated in the Partnership Agreement.

At least one general partner of a limited partnership should be a resident, or have the registered office in the EEA. A silent partner does not need to be residing or have a registered office in the EEA. If any of the general partners do not reside or have a registered office in the EEA, all the general partners should apply for a permit from the National Board of Patents and Registration. 
LIMITED COMPANY (OY / AB)

A limited company can be formed by one or more founding subscribers of shares, who can be natural or legal persons. A founding subscriber of shares does not need to reside in the EEA, i.e. they may reside or have a domicile outside the EEA.

In limited companies, there are only shareholders, not general partners. The share capital of a private limited company has no minimum amount. You can set up a private limited company without share capital or with share capital. Shareholders' liability for the debts of the company is limited to the same amount as the value of the shares they own.

Another form of limited company, besides a private limited company, is a public limited company which has to have a minimum of EUR 80,000 of share capital. The securities of a public limited company can be admitted to public trade.

All limited companies work under the legislation of the Companies Act.

CO-OPERATIVE (OSK / ANL)

A co-operative can be founded by a minimum of three persons. The founders can be natural or legal persons and the nationality or the places of residence of the founders are not significant. In all cases, the founder of a co-operative has to be a member of the cooperative. The co-operative decides the share price. However, all the shares have to be of an equal amount. 


\section{5 - LABOUR}

\section{COLLECTIVE AGREEMENTS}

In Finland, employers' unions and workers' trade unions agree upon pay and other terms of employment in a Collective Agreement.

These agreements ensure employees a minimum level of employment terms and generally the terms of the collective agreement are in favour of the employee in comparison to the common legislation. Shorter working hours, longer sick-leave payment periods and holiday pay are agreed in almost every collective agreement. There is a collective agreement in most branches of work and these bind all employers in their applicable sector. Information about where and when collective agreements are legally binding and the contents of these agreements can be found in the legislation register of the Ministry of Justice.

The minimum amount of salary payable to the employee is indicated by the collective agreement. If the employer is not a member of the employer association that has concluded the collective agreement and if there is no collective agreement that would be binding on the employer, the employer must pay a salary which is considered reasonable and usual for the work required. In these cases, the salary can be based on salary recommendations of associations in the branch.

Any agreement which diminishes the rights and interests secured for employees in the labour legislation and/or in the collective agreement is void.

\section{EMPLOYMENT CONTRACTS}

The employer and employee agree upon terms of employment in an employment contract. Employment contracts can be concluded in writing, orally or electronically. However, it is recommended that the contract is in written form and that it contains at least the name of the employer, the name of the employee, the nature of the work, the starting date of employment, the duration of the employment, the notice period, the trial period, pay and working hours.

At the beginning of the work, the employer and the employee can agree on a trial period. In general, this can last six months at most, during which the employment contract may be cancelled by the employee or employer. In the case of a fixed-term employment contract, a trial period may not exceed half the duration of the employment contract or be longer than six months.

\section{SOCIAL SECURITY}

In Finland, employers must arrange employees' pension security by taking out pension insurance for their employees. In addition, employers must notify their employees how their pension security is arranged. The employer is liable to arrange the insurance for all employees aged 17-68 years who are paid at least EUR 60.57 in one month for the same employment relationship, regardless of the length of the employment relationship. 
The employment pension premium is paid on a salary or other consideration paid or agreed to be paid as compensation for work done in an employment relationship. The compensation for work done in an employment relationship includes not only the basic salary, but also for example overtime compensation, annual leave, fringe benefits and salary or wages during illness or after an accident.

Employers have a statutory duty to take out accident insurance for employees. Accident insurance must be in place before the work starts and it must insure employees and workers against accidents and occupational diseases. Employees must also be provided with group life assurance and unemployment insurance in connection with the statutory accident insurance.

Employers are responsible for paying withheld taxes and social security contributions to the tax authorities, and for submitting monthly notifications to the tax authorities, and to the pension and accident insurance companies, with information on the wages and salaries paid to employees.

Employers must arrange occupational health care at their own cost. The intention of occupational health care is to prevent health dangers and harm resulting from work and working conditions and to promote and support the safety of work, health of the employees and their ability to work. Occupational healthcare must include the clarification and evaluation of the healthiness and safety of the work and working conditions, the clarification and evaluation of work-related health risks and damage, as well as the health status of the workers and their working ability, and an evaluation of the quality and effects of occupational healthcare. In addition, it should include proposals for any measures which should be taken to improve the healthiness and safety of work, any monitoring of a partially disabled worker in the workplace, and giving advice and guidance regarding the healthiness and safety at work. If the employers wish, they may arrange other additional healthcare services for their employees.

The Finnish labour and occupational safety legislation is applied to all employees working for Finnish employers regardless of their nationality.

\section{ANNUAL AND FAMILY LEAVES, SICK PAY}

An employee, who has worked less than a year by the end of the holiday year, is entitled to two weekdays of holiday for each full holiday credit month worked. When the employment has lasted for more than one year without interruption, the entitlement to holiday is increased to 2.5 days per each holiday credit month.

Weekdays, including Saturdays, are used in the calculation for holiday days when determining annual holiday. A full holiday credit month is defined as a calendar month of the holiday credit year, which is the calendar year from 1 April to the last day of March preceding the holiday period, during which the employee has worked at least 14 working days or during which at least 14 days are counted as working days. If the employee works so few days in accordance with the employment contract that one or more calendar months include less than 14 working days, a holiday credit month is defined as a calendar month during which the employee has worked at least 35 hours. 
An employee has a right to take leave from work during maternity, special maternity and parental benefit periods. The employee must inform the employer about the family leave at least two months before the intended start of a leave. The employer is not liable to pay salary during family leave. However, collective agreements of the branch may contain provisions on the duty of the employer to pay salary. Family leave days accrue annual holiday days and when the family leave ends, the employee has a right to return to his/her earlier work.

An employee is entitled to sick pay if he is prevented from doing his work because of an illness or accident. If the employment relationship has lasted for more than a month, the employee has a right to full sick pay for nine weekdays following the first day of illness. The employee has a right to $50 \%$ of the pay if the employment relationship has lasted less than a month. 


\section{6 - TAXATION}

\section{TAXABLE INCOME}

The net result (whether it is profit or loss) indicated by a company's books is in all cases the starting point when calculating the taxable income of a company.

However, the annual result shown by accounting is corrected according to certain items. The reason for these corrections is that the provisions of the Accounting Act and the Corporate Tax Act differ slightly from each other.

\section{INCOME TAX OF PRIVATE ENTREPRENEURSHIP}

Finland operates a dual income tax system for individuals, under which income is divided into earned income and capital income. Earned income is subject to national income tax (at progressive rates), municipal income tax, Church tax and social security contributions.

Income from capital is subject to national income tax at a flat rate of $30 \%$ on income up to EUR 30,000 and $34 \%$ for income exceeding this amount.

The net result of a business or trade activity is added to other income of an entrepreneur. The result of the undertaking is taxed so that a $20 \%$ annual yield calculated on the net property of the previous year is considered capital income. If the entrepreneur wants, he/she can demand that $10 \%$ rather than $20 \%$ is considered to be capital income. The rest is earnings income.

\section{INCOME TAX OF A GENERAL OR LIMITED PARTNERSHIP}

A general or limited partnership is not separately liable for tax. Its result is divided and taxed as income of the partners. The income is divided between the partners in accordance with their profit shares listed in the partnership agreement.

\section{INCOME TAX OF A LIMITED COMPANY}

Corporate tax is imposed on a company's profits, which consists of business income, passive income and capital gains. The corporate tax rate is $20 \%$.

Capital gains are generally treated as ordinary income and taxed the standard corporate rate of $20 \%$. However, gains on qualifying holdings are exempt if certain conditions are satisfied. Gains derived from the sale of shares are not taxable for a Finnish corporate taxpayer if the shares sold belong to fixed assets which are deemed to be part of the seller's business income-generating assets (rather than passive income), where:

- The seller company owns at least $10 \%$ of the share capital of the entity and the dividenddistributing shares contribute to this equity stake

- The shares have been held for at least one year and the alienation does not take place more than one year after the seller company's ownership in the entity falls below a $10 \%$ threshold

- The alienated shares are not shares in a real estate company or limited liability company whose business activities principally consists of governing or owning real estate

- The alienated shares are of a Finnish company or a foreign company listed in the EC parent-subsidiary directive or a company resident in a treaty country, provided the treaty applies to dividends distributed by the company. 
Tax losses may be carried forward for ten years. The right to carry forward losses is forfeited if more than $50 \%$ of the shares of the company were transferred during or after the year in which the losses were incurred. Further, if more than $50 \%$ of the shares in a company which owns at least $20 \%$ of the shares in the Finnish loss-making company have been transferred, the relevant portion of the shares in the Finnish loss-making company are deemed as transferred. The carry back of losses is not permitted.

Dividends received by a Finnish resident company from another Finnish company are generally exempt from tax. Dividends received from EU and tax treaty countries are also generally tax exempt for corporations. Dividends paid to a non-resident company are subject to a $20 \%$ withholding tax unless the rate is reduced under a tax treaty or they are exempt under the EU parent-subsidiary directive.

If the entity receiving the dividend is a natural person, the dividend distributed by a nonlisted company is tax exempt or partially taxable. $25 \%$ of the dividends from non-listed companies are regarded as taxable capital income, as long as the amount of dividend does not correspond to an $8 \%$ annual return calculated on the mathematical value of the share, up to a maximum of EUR 150,000. Of the dividend exceeding the EUR 150,000 threshold, $85 \%$ is taxable capital income. The portion exceeding an amount corresponding to an annual return of $8 \%, 75 \%$ of the dividend is taxable earned income.

\section{INCOME TAX OF CO-OPERATIVE}

All the income of a co-operative is taxed with a relative income tax rate of $20 \%$.

In the taxation of the members of a co-operative, the refund of the surplus paid to a private member is considered additional wages when the surplus is based on work performed. Any interest on co-operative capital is capital income of the member. This kind of income is completely exempt from tax up to EUR 5,000 and $85 \%$ of income exceeding this limit is considered to be capital income, with $15 \%$ exempt from tax.

\section{INCOME TAX OF BRANCH OF A FOREIGN ENTREPRENEUR}

A foreign undertaking can carry out business activity in Finland without establishing an independent subsidiary and in these cases; the result of these fixed business facilities is taxed in Finland under Finnish taxation legislation. Primarily the branches are taxed the same way as Finnish limited companies.

\section{VALUE ADDED TAXATION}

The value added taxation system (VAT) in Finland is very similar to other EU countries because of the harmonisation of VAT procedures in Europe. A value added tax is a tax on consumption which the consumer pays in the price of a product or service and the entrepreneur pays to the state. The tax burden is laid on the consumer but the party liable for the tax is the seller of the goods and services. If the seller is foreign, the liability for tax lies with the buyer unless the seller has a fixed establishment in Finland. An importer is liable to pay tax for the import of goods.

Supplies of goods and services in the form of business operations are subject to VAT in Finland. A taxable person is any person who carries out taxable activities in a business in Finland. There are certain exceptions to these main rules. For example small businesses, not-for-profit organisations, religious communities and disabled persons under certain conditions are exempted from VAT. 
If the turnover of business activities in a certain financial year does not exceed EUR 10,000, no VAT registration is usually required and no VAT is levied. If the turnover of the taxable person in a particular financial year is less than EUR 30,000, the tax liable entity may be entitled to full/partial VAT relief.

There are three VAT rates in Finland and some sales of goods and services may be exempted from VAT.

The standard VAT rate is $24 \%$. It is applied to all commercial sales of goods and services where no reduced tax rates are applicable. A reduced rate of $14 \%$ is applied to food and animal feed (excluding live animals) and restaurant and catering services (excluding alcoholic beverages and tobacco products). A reduced rate of $10 \%$ is available for items such as books, medicines, passenger transportation services, accommodation services and admissions to cultural and sporting events. Exemptions are provided e.g. for health and medical care, social welfare services, education, financial and insurance services, performing artists' fees and certain copyrights and lotteries, as well as other money games.

The sale of goods or services may be exempted from VAT where sales do not take place in Finland, if the sales do not take place within business conduct or if the sales are considered as intra-Community sales of goods. In some cases, goods or services may be exempted from VAT if the seller is a religious society, a corporation for promoting public good, a severely disabled entrepreneur or if the small-scale activity exemption can be applied to the seller.

In general, suppliers of goods and services in the form of business are always subject to VAT in Finland. This means that the company must be registered in the Finnish Tax Register. Non-resident suppliers of goods and services have an obligation to register for VAT purposes in Finland and charge Finnish VAT if they have a fixed establishment in the country. If non-resident suppliers make intra-Community acquisitions or intra-Community supplies in Finland, they are subject to notification duty. A VAT registration liability will also be created if a foreign company supplies goods or services in Finland to which the reverse charges rules do not apply. If a foreign company is liable to register for VAT purposes in Finland and it carries out business transactions subject to VAT in Finland before a VAT registration, it should be noted that the company is liable for the payment of the VAT due even though it has not yet been registered for VAT purposes in Finland.

VAT returns and payments are generally due on a monthly basis. Under certain conditions, quarterly or annual reporting and payments are alternatively available. The due date for filing VAT returns and making the payment is the 12th day of the second month following the VAT period in question. 


\section{7 - ACCOUNTING \& REPORTING}

\section{ACCOUNTS}

In Finland, accounting is compulsory for all entities carrying on a business or a trade.

The management of a company is liable to arrange the accounting and bookkeeping, which must be prepared according to good accounting practices. The Accounting Board in Finland gives general instructions and issues opinions and decisions regarding good accounting practice. Accounting is subject to the provisions of the Accounting Act and the Accounting Decree, but accounting is also guided by taxation legislation.

Listed companies must prepare their consolidated financial statements according to the International Accounting Standards (IAS) and the International Financial Reporting Standards (IFRS).

The financial statement includes the balance sheet, the income statement and the notes. Public and large limited companies are also required to give a cash flow statement.

The thresholds of a large company are as follows:

- The turnover of the corresponding yield is EUR 40.0 million

- The balance sheet total is EUR 20.0 million

- The company employs 250 persons on average

If the company exceeds more than two of the thresholds of a small company in the last financial period and in the financial period preceding it, it also has to prepare a director's report and include this in its financial statements.

The thresholds of a small company are as follows:

- The turnover of the corresponding yield is EUR 12.0 million

- The balance sheet total is EUR 6.0 million

- The company employs 50 persons on average

The financial statement must be completed within four months from the end of the financial period and certain companies must publish this by submitting it for registration with the Trade Register. All limited companies, co-operatives and partnerships with a limited company as general partner must publish their financial statements. The same is true for companies which exceed at least two of the thresholds of a small company during the financial year and the one preceding it.

Accounting material has to be kept for a minimum of six years from the end of the calendar year in which the financial period ended. All the books compiled in accounting, the balance sheet book containing the financial statement, balance sheet itemisations, accounting frameworks, entry plan and method description, have to be kept for at least ten years from the end of the financial period. The material can be retained in machine-readable form. 


\section{AUDITING REQUIREMENTS}

In Finland there is no general obligation to have an audit conducted. Private entrepreneurs do not need to have an audit conducted. The auditing obligation on other forms of business is conditional on the size of the business. If a corporation meets no more than one of the following conditions in both the closing accounting period and in the accounting period preceding it, it does not need to appoint an auditor:

- The balance sheet total exceeds EUR 100,000

- Net sales or corresponding earnings exceed EUR 200,000

- There are more than three employees on average.

If the Articles of Association, the Rules of the Cooperative or the Partnership Agreement of a general partnership or a limited partnership orders that auditing must be executed, a company cannot neglect the appointment of an auditor, even where it does not meet the conditions mentioned above.

The auditor must be a professionally competent person independent of the management of the enterprise. Auditing includes an examination of the accounting, financial statements and administration of the enterprise during the accounting period.

In Finland, the titles for authorised auditors are HT and KHT. The Auditing Act specifies the circumstances when an authorised auditor must be used.

If the organisation is subject to public trading or if at least two of the following conditions are met in the most recent accounting period, at least one of the auditors must be a KHT auditor or a KHT corporation:

- The balance sheet total exceeds EUR 25 million

- Net sales or corresponding earnings exceed EUR 50 million

- There have been more than 300 employees on average in the organisation. 
8 - UHY REPRESENTATION IN FINLAND 


\section{$\oplus$ UHY TIETOAKSELI}

FINLAND

CONTACT DETAILS

UHY TietoAkseli

Vilhonkatu $6 \mathrm{~A}$

00100 Helsinki

Finland

Tel: +358 103472800

Fax: +358103472801

www.tietoakseli.fi

\section{SOCIAL MEDIA CONNECTIONS}

- Facebook: https://www.facebook.com/TietoAkseli/

- Linkedln: https://www.linkedin.com/company/tietoakseli/

Year established: $\quad 1991$

Number of partners: 7

Total staff:

\section{CONTACTS}

Liaison contact: Mikko Akselin

Position:

Email:
Chairman of the Board

mikko.akselin@tietoakseli.fi

\section{ABOUT US}

UHY TietoAkseli is an expert in financial administration. We take our responsibility seriously and keep our promises.

\section{OTHER IN-COUNTRY OFFICE LOCATIONS AND CONTACTS}

UHY TietoAkseli

Puistokatu $2 \mathrm{C}$

FIN-40100 Jyväskylä

info@tietoakseli.fi

UHY TietoAkseli

Vilhonkatu $6 \mathrm{~A}$

00100 Helsinki

Finland

info@tietoakseli.fi

UHY TietoAkseli

Yrttipellontie 1

FIN-90230 Oulu

info@tietoakseli.fi

UHY TietoAkseli

Porrassalmenkatu 23

FIN-50100 Mikkeli

info@tietoakseli.fi

\section{BRIEF DESCRIPTION OF FIRM}

The aim of our company is to produce correct, timely and understandable financial information which helps our clients to make right decisions and to run their businesses profitably. We offer comprehensive financial and payroll administration services and consulting services. We also offer versatile operations, process and financial administration consulting and development

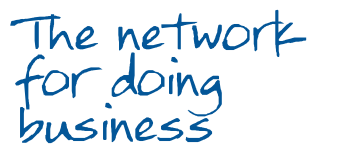




\section{$\oplus$ UHY TIETOAKSELI}

FINLAND

services.

We take care of audit, tax consulting, M\&A, bookkeeping, financial statements, tax reporting, calculation of salaries and provide any reports required to support company decision making. Service packages are always designed individually and customised according to our clients' needs. We advise clients on the development of financial administration processes and offer support during different stages of the business, both in business reorganization as well as rationalization.

Through our partners we are also offer online Accounting solutions. The SaaS model enables rapid deployment without installation costs and with no need to invest on hardware. There are no additional maintenance costs involved either.

\section{SERVICE AREAS}

Accounting and outsourcing

Payroll and human resources administration

Business advisory

Development of financial reporting and accounting procedures

Tax consultancy

Audit

Valuation of business and Due Diligence

Advice on starting a business in Finland

Online accounting solutions

\section{SPECIALIST SERVICE AREAS}

Outsourcing services

Mergers and acquisitions

Business activities development

\section{PRINCIPAL OPERATING SECTORS}

Engineering

IT consulting

Advertising and communication

Transportation services

Environmental management

Service industries

\section{LANGUAGES}

Finnish, Swedish, English.

\section{CURRENT PRINCIPAL CLIENTS}

Confidentiality precludes disclosure in this document.

OTHER COUNTRIES IN UHY CURRENTLY WORKING WITH, OR HAVE WORKED WITH IN THE PAST

Sweden

Denmark

United Kingdom

United States

Norway

The network for doing business 


\section{$\bigoplus$ UHY TIETOAKSELI}

FINLAND

\section{BRIEF HISTORY OF FIRM}

UHY TietoAkseli was established 1991 in Jyväskylä by Mikko and Sari Akselin. Since 1997 UHY TietoAkseli has been an accounting company authorized and controlled by the Association of Finnish Accounting Firms. Since 1999 UHY TietoAkseli has used a quality management system certified by DNV (Det Norske Veritas). The certification is based on the SFS-EN ISO 9001 standard.

The head office has been located in Jyväskylä since the establishment of the company in 1991. After operating for 13 years in one location, the first branch office was established in Helsinki, the capital of Finland, in 2004. Four years later the second branch office was opened in Oulu. In 2010 UHY TietoAkseli opened its fourth office in Mikkeli. Currently we operate in seven locations. The firm joined UHY in 2011.

UHY TietoAkseli specialises in financial and payroll administration services and consulting services. 
LET US HELP YOU ACHIEVE

FURTHER BUSINESS SUCCESS

To find out how UHY can assist your business, contact any of our member firms. You can visit us online at www.uhy.com to find contact details for all of our offices, or email us at info@uhy.com for further information.

UHY is an international network of legally independent accounting and consultancy firms whose administrative entity is Urbach Hacker Young International Limited, a UK company. UHY is the brand name for the UHY international network. Services to clients are provided by member firms and not by Urbach Hacker Young International Limited. Neither Urbach Hacker Young International Limited, the UHY network, nor any member of UHY has any liability for services provided by other members.

UHY TietoAkseli (the "Firm") is a member of Urbach Hacker Young International Limited, a UK company, and forms part of the international UHY network of legally independent accounting and consulting firms. UHY is the brand name for the UHY international network. The services described herein are provided by the Firm and not by UHY or any other member firm of UHY. Neither UHY nor any member of UHY has any liability for services provided by other members.

(C) 2020 UHY International Ltd 